Molecules 2004, 9, 939-948

molecules

ISSN 1420-3049

http://www.mdpi.org

\title{
Asymmetric Synthesis and Antimicrobial Activity of Some New Mono and Bicyclic $\beta$-Lactams
}

\author{
A. A. Jarrahpour ${ }^{1, *}$, M. Shekarriz ${ }^{1}$ and A. Taslimi $^{2}$ \\ ${ }^{1}$ Chemistry Department, College of Sciences, Shiraz University, Shiraz 71454, Iran. Tel.: (+98) 711 \\ 228 4822, Fax: (+98) 7112280926 \\ ${ }^{2}$ Institute of Standards and Industrial Research of Iran, Shiraz 71447, Iran
}

Author to whom correspondence should be addressed; e-mail: jarrah@susc.ac.ir, aliasghar6683@yahoo.com

Received: 24 September 2003; in revised form: 31 August 2004 / Published: 30 November 2004

\begin{abstract}
Reaction of the amino acid D-phenylalanine ethyl ester (4) with cinnamaldehyde gave chiral Schiff base 5, which underwent an asymmetric Staudinger $[2+2]$ cycloaddition reaction with phthalimidoacetyl chloride to give the monocyclic $\beta$-lactam 6 as a single stereoisomer. Ozonolysis of $\mathbf{6}$ followed by reduction with lithium aluminum tri(tert-butoxy) hydride afforded the hydroxymethyl $\beta$-lactam $\mathbf{8}$. Treatment of 8 with methansulfonyl chloride gave the mesylated monocyclic $\beta$-lactam 9, which was converted to the bicyclic $\beta$-lactam 10 upon treatment with 1,8-diazabicyclo[5,4.0] undec7-ene (DBU). Deprotection of the phthalimido group in $\beta$-lactams $\mathbf{6}$ and $\mathbf{1 0}$ by methylhydrazine and subsequent acylation of the free amino $\beta$-lactams with different acyl chlorides in the presence of pyridine afforded mono and bicyclic $\beta$-lactams 14a-d and 15a-d respectively. The compounds prepared were tested against Escherichia coli, Staphilococcus citrus, Klebsiella pneumanie and Bacillus subtillis. Some of these compounds showed potential antimicrobial activities.
\end{abstract}

Keywords: D-Phenylalanine, asymmetric induction, chiral Schiff base, DBU, antimicrobial 


\section{Introduction}

The $\beta$-lactam skeleton is the key structural element of the most widely used class of antimicrobial agents, the $\beta$-lactam antibiotics [1]. Among the various methods for constructing this pharmaceutically important four-membered ring, the ketene-imine cycloaddition, also known as the Staudinger reaction [2] has provided useful and economical entries to $\beta$-lactams, mainly due to the ready availability of both Schiff bases and ketenes [3]. The asymmetric syntheses of $\alpha$-amino $\beta$-lactams can be divided into five categories: a) asymmetric induction from the imine component; b) asymmetric induction from the ketene component; c) double stereodifferentiating cycloadditions; d) carbacephem intermediates and e) 2-oxaisocephems and 2-isocephems [1]. The asymmetric induction in the reaction of achiral ketenes with chiral imines has been effected from imines derived from chiral aldehydes and achiral amines and also from imines derived from chiral amines and achiral aldehydes. Although it is believed that the former case is better for diastereoselectivity, it has been reported that the reaction of the imine derived from D-glucosamine and cinnamaldehyde with phthalimidoacetyl chloride and triethylamine furnished the $\beta$-lactam 1 as a single isomer [4]. It has also been found that the imine derived from the amino acid D-threonine upon treatment with azidoacetyl choride and triethylamine affords $\beta$-lactams 2 and $\mathbf{3}$ in a 95:5 stereoisomeric ratio [5]. Gunda has reported the use of imines derived from chiral amines in $\beta$ lactam syntheses giving various degrees of diastereoselectivity [6]. The reaction of fluoroacetyl chloride with the imine derived from $\mathrm{p}$-anisidine and D-glyceraldehyde acetonide afforded the corresponding cis $\beta$-lactam as a single diastereomer [7]. High levels of asymmetric induction in reactions between Evans-Sjogren ketenes and imines derived from (R)- and (S)- $\alpha$-amino acid esters have been reported [8].

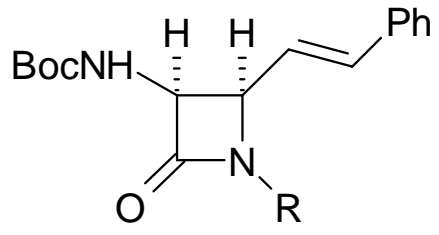

1

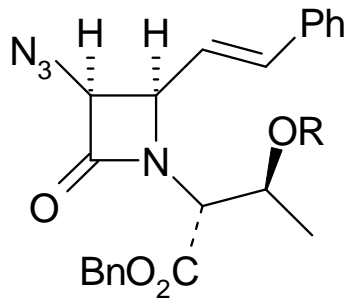

2

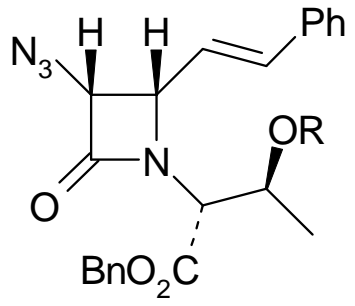

3

Hashimoto and his coworkers have used chiral imines derived from erythro 2-methoxy-1,2diphenylethylamine and aromatic aldehydes to prepare $\beta$-lactams in good yields with high diastereoselectivity [9]. Recently, high levels of asymmetric induction have also been reported for monocyclic $\beta$-lactam formation [10-11]. Thus, we decided to synthesize some diastereoselective mono and bicyclic $\beta$-lactams using the asymmetric induction by the imine component and their antimicrobial activities against some pathogenic microorganisms have been tested. 


\section{Results and Discussion}

D-Phenylalanine ethyl ester (4) was reacted with cinnamaldehyde in dry dichloromethane according to a reported method to afford the chiral imine phenylalanine( $\mathrm{N}$-cinnamylidene) ethyl ester (5) in $85 \%$ yield [12]. A solution of phthalimidoacetyl chloride was slowly added at $-10^{\circ} \mathrm{C}$ to a solution of chiral Schiff base 5 and triethylamine in dry methylene chloride. This method of addition produced the cis $\beta$-lactam 6 as a single stereoisomer in 80\% yield [13-16]. The expected cisconfiguration of 6 was confirmed by ${ }^{1} \mathrm{H}-\mathrm{NMR}$, which showed a characteristic coupling constant of about $5 \mathrm{~Hz}$ for the $\beta$-lactam protons [17-18]. Ozonolysis of $\beta$-lactam 6 at $-78^{\circ} \mathrm{C}$ afforded the formyl $\beta$ lactam 7 in $90 \%$ yield. The formyl $\beta$-lactam was reduced to the 4-hydroxymethyl $\beta$-lactam 8 in $60 \%$ yield by treatment with lithium tri(tert-butoxy)aluminium hydride in dry THF. Mesylation of 8 with methanesulfonyl chloride and triethylamine at $-78^{\circ} \mathrm{C}$ in dichloromethane gave $\beta$-lactam 9 . The mesyl $\beta$-lactam 9 was treated with 1,5-diazabicyclo[5.4.0] undec-5-ene (DBU) in 9:1 THF-DMF at reflux temperature for four hours to give 6-phthalimido-7-oxo-3-phenyl-1-azabicyclo[3.2.0] heptane-2carboxylic acid ethyl ester (10) as a yellow solid in 20\% yield (Scheme 1).

\section{Scheme 1}

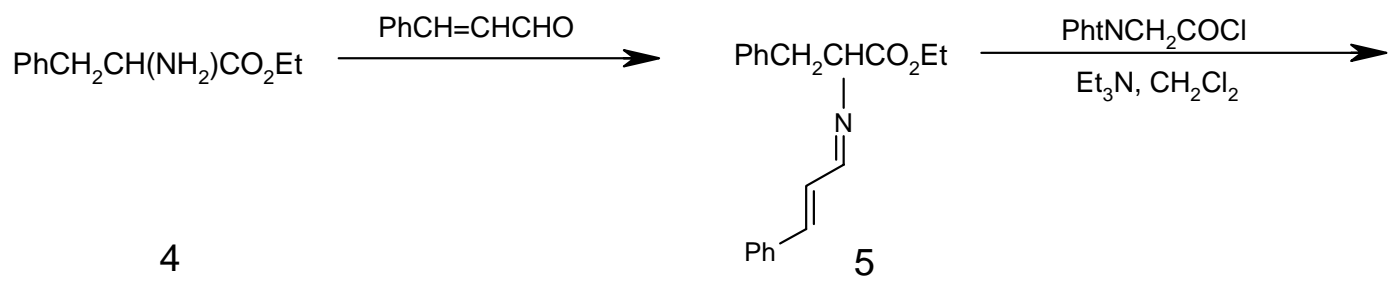

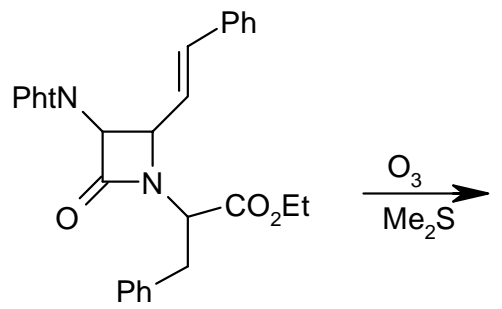

6<smiles>CCOC(=O)C(Cc1ccccc1)N1C(=O)C(Nc2ccccc2)C1C=O</smiles>

7

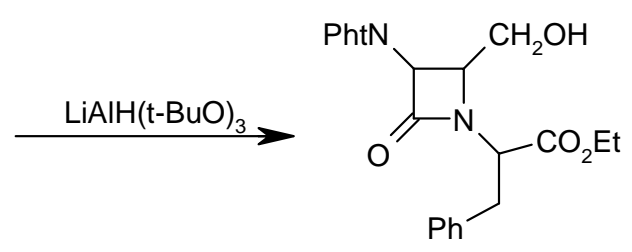

8

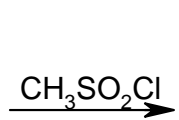<smiles>CCOC(=O)C(Cc1ccccc1)N1C(=O)C(Nc2ccccc2)C1COS(C)(=O)=O</smiles>

9<smiles>CCOC(=O)C1C(c2ccccc2)CC2C(Nc3ccccc3)C(=O)N21</smiles> 
Although the $\alpha$-hydrogen in the $\mathrm{NCHCO}_{2}$ Et group of 9 is more acidic than the benzylic hydrogens, the abstraction of benzylic hydrogen leads to the formation of five-membered ring which is thermodinamically more stable than the fused four-membered ring $\mathbf{1 1}$ that would result from the alternate cyclization.

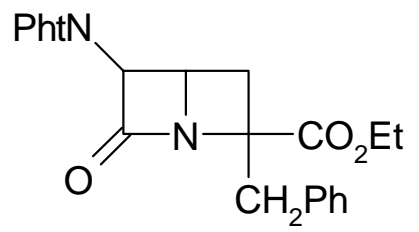

11

In addition, the absence of a singlet peak for the benzylic protons in ${ }^{1} \mathrm{H}-\mathrm{NMR}$ spectrum of $\mathbf{1 1}$ confirms the formation of bicyclic $\beta$-lactam 10. The IR spectrum showed the $\beta$-lactam carbonyl absorption at $1780 \mathrm{~cm}^{-1}$ for $\mathbf{1 0}$ which has increased a little due to fusing two rings and subsequently the amide resonance is lowered. We next turned to the deprotection of the phthalimido protecting groups of $\beta$-lactams $\mathbf{6}$ and $\mathbf{1 0}$ (Scheme 2).

Scheme 2

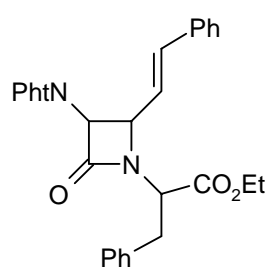

6

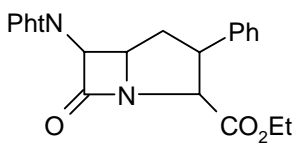

10

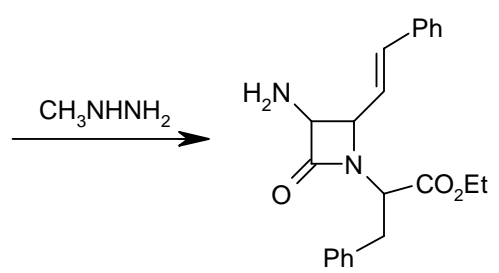

12

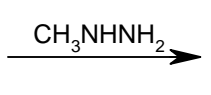

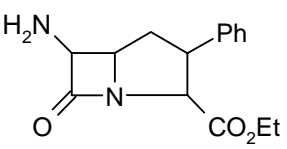

13

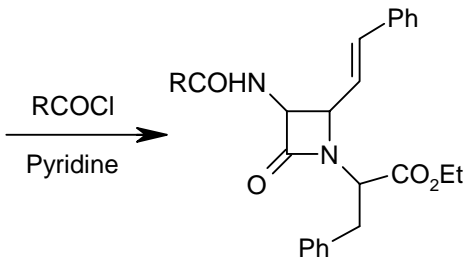

$14 a-d$

b) $\mathrm{R}=-\mathrm{CH}_{2} \mathrm{Ph} \quad$ d) $\mathrm{R}=-\mathrm{CH}=\mathrm{CHPh}$

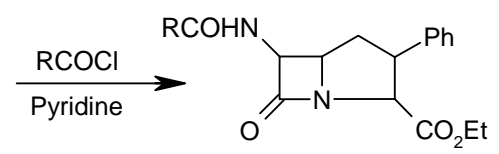

$15 a-d$
a) $\mathrm{R}=\mathrm{Ph}$
c) $\mathrm{R}=-\mathrm{CH}_{2} \mathrm{OPh}$
b) $\mathrm{R}=-\mathrm{CH}_{2} \mathrm{Ph}$ d) $\mathrm{R}=-\mathrm{CH}=\mathrm{CHPh}$

Among the different methods available for this kind of deprotection, the one using methylhydrazine worked best in this case [19-22] and a significant improvement in the yield and in the ease of isolation of the free amino $\beta$-lactam is noted when methylhydrazine is employed instead of the usual hydrazine. This is due to the decreased acidity of the by-product N-methylphthalhydrazide with respect to phthalhydrazide and hence no complex is formed with the free amine. Consequently there is 
no need to heat or for acid treatment of the reaction mixture. N-methylphthalhydrazide separates from a chloroform solution of the methylhydrazine-phthalisoimide adduct leaving the free amine in solution. Therefore the methylhydrazine method is most suitable for sensitive substrates [21]. Upon treatment with methylhydrazine, $\beta$-lactams 6 and 10 were converted to free amino $\beta$-lactams 12 and 13 respectively.Treatment of these mono and bicyclic $\beta$-lactams with benzoyl, phenoxyacetyl, cinnamoyl and phenylacetyl chloride in the presence of pyridine afforded $\beta$-lactams 14a-d and 15a-d in moderate yields

\section{Biological Screening. Antimicrobial Activity Tests}

The antimicrobial activity test was performed using the disk diffusion method [23] using ampicillin and gentamycin as the reference compounds. Some of the prepared compounds: 6, 7, 8, 10, 14a-d and 15a-d were tested against one strain each of a Gram positive bacteria (Staphylococcus citrus), a Gram negative bacteria (Escherichia coli), a Gram negative containing capsule (Klebsiella), and a Gram positive spore (Bacillus subtilis). As shown in Table 1, it was found that compounds 6, 14b and 14c were highly active against Bacillus subtilis and moderately active against Staphilococcus citrus. Other compounds were all inactive against these four pathogenic microorganisms.

Table 1. Results of antimicrobial activity tests of the synthetic monocyclic and bicyclic $\beta$-lactams.

\begin{tabular}{|c|c|c|c|c|}
\hline \multirow{2}{*}{ Compound No. } & \multicolumn{4}{|c|}{ Microorganism } \\
\cline { 2 - 5 } & B. Subtilis & K. Pneumoniae & E. coli & S. citrus \\
\hline Ampicillin & +++ & +++ & +++ & +++ \\
Gentamycin & +++ & +++ & +++ & +++ \\
6 & +++ & - & - & ++ \\
7 & - & - & - & - \\
8 & - & - & - & - \\
10 & - & - & - & - \\
14a & - & - & - & - \\
14b & +++ & - & - & ++ \\
14c & +++ & - & - & - \\
14d & - & - & - & - \\
15a & - & - & - & - \\
15b & - & - & - & - \\
15c & - & - & - & - \\
15d & - & - & - & - \\
\hline
\end{tabular}

Key to symbols: Highly active +++ (inhibition zone $>12 \mathrm{~mm}$ ); Moderately active ++ (inhibition zone 9-12 mm); Slightly active + (inhibition zone 6-9 mm); Inactive - (inhibition zone<6 mm). 


\section{Acknowledgements}

The authors wish to express their thanks to Research Council of Shiraz University for financial support (Grant No 83-GR-SC-31).

\section{Experimental}

\section{General}

Melting points were determined in open capillary tubes in a Buchi 510 circulating oil apparatus and are uncorrected. Infrared spectra were recorded on a Perkin Elmer 781 spectrophotometer. ${ }^{1} \mathrm{H}-\mathrm{NMR}$ spectra were recorded at room temperature for $\mathrm{CDCl}_{3}$ solutions, (unless otherwise stated) on a Jeol JNM-EX 90A FT NMR and Bruker Avance DPX $250 \mathrm{MHz}$ spectrometers using tetramethylsilane as an internal standard. All chemical shifts are reported as $\delta$ values (ppm). Mass spectra were obtained on a GCMS-QP 1000 EX mass spectrometer $(70 \mathrm{eV})$. The microorganism strains used in this study were $\beta$-lactam sensitive ones.

\section{Ethyl $\alpha$-amino-(N-cinnamylidene)- $\beta$-phenyl propionate (5)}

A mixture of cinnamaldehyde $(1.50 \mathrm{ml}, 10.00 \mathrm{mmol})$, D-phenylalanine ethyl ester $(4,2.00 \mathrm{~g}, 10.00$ mmol), triethylamine $(1.01 \mathrm{~g}, 10.00 \mathrm{mmol})$, and $\mathrm{Na}_{2} \mathrm{SO}_{4}(10.00 \mathrm{~g}, 72.40 \mathrm{mmol})$ in dry methylene chloride $(40.00 \mathrm{~mL})$ was refluxed for 5 hours. The resulting mixture was filtered and washed with $\mathrm{H}_{2} \mathrm{O}$ $(3 \times 30 \mathrm{~mL})$. The organic layer was separated and dried $\left(\mathrm{Na}_{2} \mathrm{SO}_{4}\right)$. Evaporation of the solvent under reduced pressure gave the chiral Schiff base 5 as a solid which was recrystallized from ethanol $(2.50 \mathrm{~g}$, $81 \%$ ); m.p. $130-132^{\circ} \mathrm{C}$; ${ }^{1} \mathrm{H}-\mathrm{NMR}: 1.30\left(3 \mathrm{H}, \mathrm{t}, \mathrm{CH}_{3}\right), 3.45\left(2 \mathrm{H}, \mathrm{d}, \mathrm{PhCH}_{2}\right), 4.34\left(2 \mathrm{H}, \mathrm{q}, \mathrm{OCH}_{2} \mathrm{CH}_{3}\right)$, $4.40\left(1 \mathrm{H}, \mathrm{t}, \underline{\mathrm{CHCO}}{ }_{2} \mathrm{Et}\right), 5.85(1 \mathrm{H}, \mathrm{d}, \mathrm{J}=15 \mathrm{~Hz}, \mathrm{PhCH}=\mathrm{CH}), 6.45(1 \mathrm{H}, \mathrm{dd}, \mathrm{J}=15 \mathrm{~Hz}, \mathrm{PHCH}=\mathrm{CHCH})$, 7.20-7.40 (10H, m, 2Ph), $8.30(\underline{\mathrm{CH}}=\mathrm{N}) ; \mathrm{IR}(\mathrm{KBr})\left(\mathrm{cm}^{-1}\right): 1640(\mathrm{C}=\mathrm{N}), 1740(\mathrm{COOEt}) ; \mathrm{MS}(\mathrm{m} / \mathrm{z}): 307$ $\left(\mathrm{M}^{+}\right), 235(\mathrm{M}-\mathrm{COOEt}), 193(\mathrm{M}-\mathrm{PhCH}=\mathrm{CHCH}=\mathrm{N}), 104\left(\mathrm{PhCH}_{2} \mathrm{CH}\right), 91\left(\mathrm{PhCH}_{2}\right), 77(\mathrm{Ph})$; Anal. Calc. for $\mathrm{C}_{20} \mathrm{H}_{21} \mathrm{NO}_{2}$ : C, 78.15; H, 6.98; N, 4.56\%; found: C, 78.20; H, 6.80; N, 4.60\%

\section{$N$-( $\alpha$-Carboethoxy- $\beta$-phenylethyl)-3-phthalimido-4-styryl-2-azetidinone (6)}

To a solution of chiral Schiff base $5(3.07 \mathrm{~g}, 10.00 \mathrm{mmol})$ and triethylamine $(1.01 \mathrm{~g}, 10.00 \mathrm{mmol})$ in dry methylene chloride $(70 \mathrm{~mL})$ at $-10^{\circ} \mathrm{C}$ was added phthalimidoacetyl chloride $(3.00 \mathrm{~g}, 15.00$ $\mathrm{mmol})$ in dry methylene chloride $(30.00 \mathrm{~mL})$ dropwise. After the addition was complete, the solution was stirred at room temperature for 24 hours, then the reaction mixture was washed with water ( $3 \times 30$ $\mathrm{mL})$. The organic layer was separated and dried $\left(\mathrm{Na}_{2} \mathrm{SO}_{4}\right)$, filtered and the solvent was evaporated under reduced pressure to give the $\beta$-lactam 6 as a solid that was recrystallized (from ethanol) in $70 \%$ yield; m.p. $152-154^{\circ} \mathrm{C}$; ${ }^{1} \mathrm{H}-\mathrm{NMR}: 1.30\left(3 \mathrm{H}, \mathrm{t}, \mathrm{CH}_{3}\right), 3.45\left(2 \mathrm{H}, \mathrm{d}, \mathrm{PhCH}_{2}\right) 4.34\left(2 \mathrm{H}, \mathrm{q}, \mathrm{OCH}_{2} \mathrm{CH}_{3}\right)$, 
$4.40\left(1 \mathrm{H}, \mathrm{t}, \underline{\mathrm{CHCO}}{ }_{2} \mathrm{Et}\right), 4.48(1 \mathrm{H}, \mathrm{dd}, \mathrm{J}=5.5 \mathrm{~Hz}, \underline{\mathrm{CHCH}}=\mathrm{CH}), 4.60\left(1 \mathrm{H}, \mathrm{s}, \underline{\mathrm{CHN}}(\mathrm{CO})_{2}\right), 5.85(1 \mathrm{H}, \mathrm{dd}$, $\mathrm{PhCH}=\mathrm{CH}, \mathrm{J}=16 \mathrm{~Hz}), 6.4(1 \mathrm{H}, \mathrm{d}, \mathrm{J}=12 \mathrm{Hx}, \mathrm{PhCH}=\underline{\mathrm{CH}}), 7.20\left(5 \mathrm{H}, \mathrm{m}, \underline{\mathrm{PhCH}_{2}}\right), 7.40(5 \mathrm{H}, \mathrm{m}$, $\underline{\mathrm{PhCH}}=\mathrm{CH}), 7.76\left(4 \mathrm{H}, \mathrm{m}, \underline{\mathrm{C}}_{6} \underline{\mathrm{H}}_{4}(\mathrm{CO})_{2} \mathrm{~N}\right), \mathrm{IR}(\mathrm{KBr})\left(\mathrm{cm}^{-1}\right), 1780$ ( $\beta$-lactam CO), $1740\left(\mathrm{CO}_{2} \mathrm{Et}\right), 1730$, 1770 (phthalimido CO); MS (m/z): $494\left(\mathrm{M}^{+}\right), 421\left(\mathrm{M}^{+}-\mathrm{CO}_{2} \mathrm{Et}\right), 308\left(\mathrm{M}^{+}-\mathrm{COCHPhtN}\right), 234\left(\mathrm{M}^{+}-\right.$ $\left.\mathrm{CO}_{2} \mathrm{Et}_{-} \mathrm{COCHC}_{6} \mathrm{H}_{4}(\mathrm{CO})_{2} \mathrm{~N}\right), 146\left(\mathrm{C}_{6} \mathrm{H}_{4}(\mathrm{CO})_{2} \mathrm{~N}\right), 104\left(\mathrm{PhCH}_{2} \mathrm{CH}\right), 91\left(\mathrm{PhCH}_{2}\right)$; Anal. Calc. for $\mathrm{C}_{30} \mathrm{H}_{26} \mathrm{~N}_{2} \mathrm{O}_{5}:$ C, 72.86; H, 5.30; N, 5.66\%; found: C, 72.80; H, 5.20; N, 5.70\%

\section{$N$-( $\alpha$-Carboethoxy- $\beta$-phenylethyl)-3-phthalimido-4-formyl-2-azetidinone (7)}

$\beta$-Lactam $6(2.48 \mathrm{~g}, 5.00 \mathrm{mmol})$ in dry $\mathrm{CH}_{2} \mathrm{Cl}_{2}(50 \mathrm{~mL})$ was saturated with $\mathrm{N}_{2}$ at $-78^{\circ} \mathrm{C}$, then a mixture of $\mathrm{O}_{3} / \mathrm{N}_{2}$ was bubbled in until KI-starch paper showed excess ozone (15 min), which was then removed by passing a stream of $\mathrm{N}_{2}$ for $10 \mathrm{~min}$. Dimethyl sulfide $(0.75 \mathrm{~g}, 12.00 \mathrm{mmol})$ was added and the temperature of the solution was allowed to rise to $25^{\circ}$ over $1 \mathrm{~h}$. The reaction mixture was washed with $\mathrm{H}_{2} \mathrm{O}(3 \times 40 \mathrm{~mL})$ and with saturated brine $(2 \times 30 \mathrm{~mL})$. The organic layer was separated and dried $\left(\mathrm{Na}_{2} \mathrm{SO}_{4}\right)$. Evaporation of the solvent gave a syrup. The oily residue was heated under high vacuum for 20 hours at $50^{\circ} \mathrm{C}$ to remove benzaldehyde. The product 7 was obtained as a brownish oil (1.89 g, 90\%); ${ }^{1} \mathrm{H}-\mathrm{NMR}: 1.30\left(3 \mathrm{H}, \mathrm{t}, \mathrm{CH}_{3}\right), 3.45\left(2 \mathrm{H}, \mathrm{d}, \mathrm{PhCH}_{2}\right), 4.34\left(2 \mathrm{H}, \mathrm{q}, \mathrm{OCH}_{2} \mathrm{CH}_{3}\right), 4.5(1 \mathrm{H}, \mathrm{t}$,

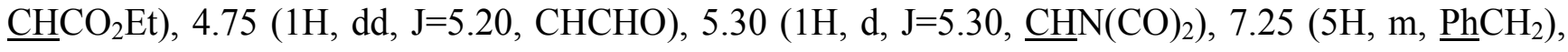
$7.80\left(4 \mathrm{H}, \mathrm{m}, \underline{\mathrm{C}}_{6} \underline{\mathrm{H}}_{4}(\mathrm{CO})_{2} \mathrm{~N}\right), 9.62(1 \mathrm{H}, \mathrm{d}, \mathrm{CHO}) ; \mathrm{IR}\left(\mathrm{CDCl}_{3}\right)\left(\mathrm{cm}^{-1}\right): 1790$ ( $\beta$-lactam CO), 1730, 1770 (phthalimido CO), $1760\left(\mathrm{CO}_{2} \mathrm{Et}\right), 1740(\mathrm{CHO}) ; \mathrm{MS}(\mathrm{m} / \mathrm{z}): 420\left(\mathrm{M}^{+}\right), 39\left(\mathrm{M}^{+}-\mathrm{CHO}\right), 105\left(\mathrm{PhCH}_{2} \mathrm{CH}_{2}\right)$, $77(\mathrm{Ph})$. Anal. Calc. for $\mathrm{C}_{23} \mathrm{H}_{20} \mathrm{~N}_{2} \mathrm{O}_{6}: \mathrm{C}, 65.71 ; \mathrm{H}, 4.79 ; \mathrm{N}, 6.66 \%$; found: C, 65.80; H, 4.69; N, 6.56\%

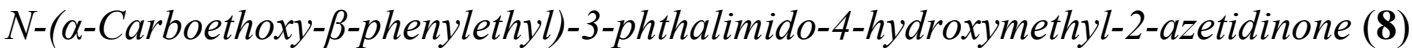

To aldehyde $7(1.50 \mathrm{~g}, 3.50 \mathrm{mmol})$ in tetrahydrofuran $(80 \mathrm{~mL})$ at $0^{\circ} \mathrm{C}$ was added lithium tri(tertbutoxy)aluminium hydride $(1.78 \mathrm{~g}, 7.00 \mathrm{mmol})$. After stirring under nitrogen for $3 \mathrm{~h}$ at $0^{\circ} \mathrm{C}$, the mixture was acidified with dilute hydrochloric acid (2\%) to $\mathrm{pH} 5$ and silica gel $(1.00 \mathrm{~g})$ was added. The suspension was stirred for 10 minutes, filtered and the solvent was evaporated. Ethyl acetate (60 $\mathrm{mL}$ ) was added to the residue and the organic phase was washed with brine $(3 \times 30 \mathrm{~mL})$, dried over $\mathrm{Na}_{2} \mathrm{SO}_{4}$ and the solvent was evaporated. The crude alcohol 8 was chromatographed on silica gel. Elution with chloroform-ethyl acetate (9:1) afforded 8 as an oil in $60 \%$ yield; ${ }^{1} \mathrm{H}-\mathrm{NMR}$ : $1.30(3 \mathrm{H}, \mathrm{t}$, $\left.\mathrm{CH}_{3}\right), 3.45\left(2 \mathrm{H}, \mathrm{d}, \mathrm{PhCH}_{2}\right), 3.75\left(2 \mathrm{H}, \mathrm{d}, \underline{\mathrm{CH}}_{2} \mathrm{OH}\right), 4.34\left(2 \mathrm{H}, \mathrm{q}, \underline{\mathrm{CH}}_{2} \mathrm{CH}_{3}\right), 4.40\left(1 \mathrm{H}, \mathrm{t}, \underline{\mathrm{CHCO}}{ }_{2} \mathrm{Et}\right), 4.65$ $(1 \mathrm{H}, \mathrm{br}, \mathrm{OH}), 4.75\left(1 \mathrm{H}, \mathrm{m}, \underline{\mathrm{CHCH}_{2} \mathrm{OH}}\right), 5.30\left(1 \mathrm{H}, \mathrm{d}, \mathrm{J}=5.20, \underline{\mathrm{CHCHCH}_{2} \mathrm{OH}}\right), 7.25\left(5 \mathrm{H}, \mathrm{m}, \underline{\mathrm{PhCH}}_{2}\right)$, $7.80\left(4 \mathrm{H}, \mathrm{m}, \mathrm{C}_{6} \mathrm{H}_{4}(\mathrm{CO})_{2} \mathrm{~N}\right)$; IR $\left(\mathrm{CH}_{2} \mathrm{Cl}_{2}\right)\left(\mathrm{cm}^{-1}\right)$ : 3300-3490 (OH), 1780 ( $\beta$-lactam CO), 1765, 1720 (phthalimido CO), $1740\left(\mathrm{CO}_{2} \mathrm{Et}\right) ; \mathrm{MS}(\mathrm{m} / \mathrm{z})$ 422( $\left.\mathrm{M}^{+}\right), 421\left(\mathrm{M}^{+}-1\right), 407\left(\mathrm{M}^{+}-\mathrm{CH}_{3}\right), 236\left(\mathrm{M}^{+}-\right.$ $\left.\mathrm{COCHC}_{6} \mathrm{H}_{4}(\mathrm{CO})_{2} \mathrm{~N}\right), 187\left(\mathrm{COCHC}_{6} \mathrm{H}_{4}(\mathrm{CO})_{2} \mathrm{~N}\right), 104\left(\mathrm{PhCH}_{2} \mathrm{CH}\right), 91\left(\mathrm{PhCH}_{2}\right), 77(\mathrm{Ph})$; Anal. Calc. for $\mathrm{C}_{23} \mathrm{H}_{22} \mathrm{~N}_{2} \mathrm{O}_{6}: \mathrm{C}, 65.40 ; \mathrm{H}, 5.25 ; \mathrm{N}, 6.63 \%$; found: $\mathrm{C}, 65.38 ; \mathrm{H}, 5.30 ; \mathrm{N}, 6.70 \%$. 


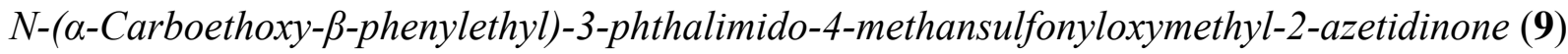

Methansulfonyl chloride $(0.27 \mathrm{~g}, 2.35 \mathrm{mmol})$ in $\mathrm{CH}_{2} \mathrm{Cl}_{2}(3 \mathrm{~mL})$ was added dropwise at $-78^{\circ} \mathrm{C}$ to alcohol 8 (1.00 g, $2.35 \mathrm{mmol})$ and triethylamine $(0.47 \mathrm{~g}, 4.7 \mathrm{mmol})$ in dry $\mathrm{CH}_{2} \mathrm{Cl}_{2}(25 \mathrm{~mL})$. After the addition was complete, the mixture was washed with $\mathrm{pH} 4.40$ buffer $\left(0.20 \mathrm{M}, \mathrm{NaH}_{2} \mathrm{PO}_{4}\right.$ solution $)$ and water $(2 \times 30 \mathrm{~mL})$, dried over $\mathrm{Na}_{2} \mathrm{SO}_{4}$ and the solvent was evaporated under reduced pressure. The residue was purified by column chromatography on silica gel. Elution with chloroform gave $\mathbf{9}$ as an oil in $60 \%$ yield; ${ }^{1} \mathrm{H}-\mathrm{NMR}: 1.30\left(3 \mathrm{H}, \mathrm{t}, \mathrm{CH}_{3}\right), 2.85\left(3 \mathrm{H}, \mathrm{s}, \mathrm{OSO}_{2} \underline{\mathrm{CH}}_{3}\right), 3.45\left(2 \mathrm{H}, \mathrm{d}, \mathrm{PhCH}_{2}\right), 3.96(1 \mathrm{H}, \mathrm{m}$,

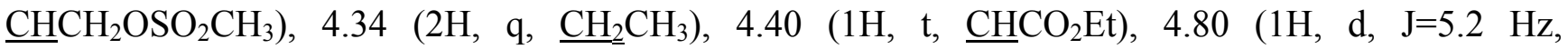

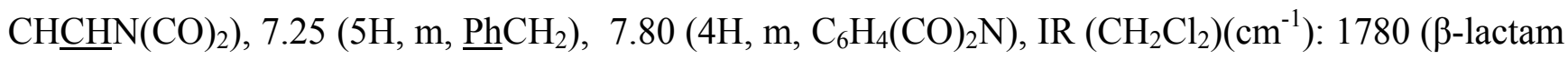
$\mathrm{CO}), 1765,1725$ (phthalimido CO), $1740\left(\mathrm{CO}_{2} \mathrm{Et}\right), 1380,1180\left(\mathrm{SO}_{2}\right)$; $\mathrm{MS}(\mathrm{m} / \mathrm{z}): 500\left(\mathrm{M}^{+}\right), 485\left(\mathrm{M}^{+}-\right.$ $\left.\mathrm{CH}_{3}\right), 314\left(\mathrm{M}^{+}-\mathrm{COCHC}_{6} \mathrm{H}_{4}(\mathrm{CO})_{2} \mathrm{~N}\right), 187\left(\mathrm{COCHC}_{6} \mathrm{H}_{4}(\mathrm{CO})_{2} \mathrm{~N}\right)$, $95\left(\mathrm{SO}_{3} \mathrm{CH}_{3}\right)$; Anal. Calc. for $\mathrm{C}_{24} \mathrm{H}_{24} \mathrm{~N}_{2} \mathrm{O}_{8} \mathrm{~S}$ : C, 57.59; H, 4.83; N, 5.60; S, 6.41\%; found: C, 57.65; H, 4.90; N, 5.50; S, 6.50\%

6-Phthalimido-7-oxo-3-phenyl-1-azabicyclo [3.2.0] heptane-2-carboxylic acid ethyl ester (10)

1,8-Diazabicyclo [5.4.0] undec-7-ene $(1.53 \mathrm{~g}, 10.00 \mathrm{mmol})$ was added to mesylate $\beta$-lactam 9 (2.02 $\mathrm{g}, 5.00 \mathrm{mmol})$ in THF-DMF 9:1 $(20 \mathrm{~mL})$. The mixture was refluxed for four hours and then the solvent was evaporated. Ethyl acetate $(30 \mathrm{~mL})$ was added to the residue and washed with water $(2 \times 30 \mathrm{~mL})$, dried over $\mathrm{Na}_{2} \mathrm{SO}_{4}$ and the sovlent was evaporated under reduced pressured to give the crude product which was chromatographed on silica gel. Elution with 1:1 n-hexane-dichloromethane afforded yellow crystals of 10 in $20 \%$ yield, m.p. $97^{\circ} \mathrm{C}$; ${ }^{1} \mathrm{H}-\mathrm{NMR}: 1.30\left(3 \mathrm{H}, \mathrm{t}, \mathrm{CH}_{3}\right), 2.20\left(2 \mathrm{H}, \mathrm{m}, \mathrm{CHCH}_{2} \mathrm{CH}\right), 3.85-$ $3.90\left(2 \mathrm{H}, \mathrm{m}, \underline{\mathrm{CHCH}_{2}} \underline{\mathrm{CH}}\right), 4.30\left(2 \mathrm{H}, \mathrm{q}, \underline{\mathrm{CH}_{2}} \mathrm{CH}_{3}\right), 4.60\left(1 \mathrm{H}, \mathrm{d}, \mathrm{J}=16 \mathrm{~Hz}, \mathrm{NCHCO}_{2} \mathrm{Et}\right), 4.95(1 \mathrm{H}, \mathrm{d}$, $\left.\mathrm{J}=5.2 \mathrm{~Hz}, \underline{\mathrm{CH}}(\mathrm{CO})_{2} \mathrm{~N}\right), 7.10(5 \mathrm{H}, \mathrm{m}, \mathrm{Ph}), 7.50-7.80\left(4 \mathrm{H}, \mathrm{m}, \mathrm{C}_{6} \mathrm{H}_{4}(\mathrm{CO})_{2} \mathrm{~N}\right)$; IR $(\mathrm{KBr})\left(\mathrm{cm}^{-1}\right): 1780(\beta-$ lactam CO), 1755, 1735 (phthalimido CO), $1720\left(\mathrm{CO}_{2} \mathrm{Et}\right) ; \mathrm{MS}(\mathrm{m} / \mathrm{z}): 404\left(\mathrm{M}^{+}\right), 389\left(\mathrm{M}^{+}-\mathrm{CH}_{3}\right), 217$ $\left(\mathrm{M}^{+}-\mathrm{COCHC}_{6} \mathrm{H}_{4}(\mathrm{CO})_{2} \mathrm{~N}\right), 187\left(\mathrm{COCHC}_{6} \mathrm{H}_{4}(\mathrm{CO})_{2} \mathrm{~N}\right), 77(\mathrm{Ph})$; Anal. Calc. for $\mathrm{C}_{23} \mathrm{H}_{20} \mathrm{~N}_{2} \mathrm{O}_{5}$ : C, 68.31; H, 4.98; N, 6.93;\%; found; C, 68.40; H, 5.05; N, 6.90\%

\section{General procedure for dephthaloylation of protected $\beta$-lactam $\mathbf{6}$}

The monocyclic $\beta$-lactam 6 (4.94 g, $10.00 \mathrm{mmol})$ was dissolved in ethanol $(25 \mathrm{~mL})$ and methylhydrazine $(0.046 \mathrm{~g}, 10.00 \mathrm{mmol})$ was added. After refluxing for 2 hours, the reaction mixture was stored overnight and then concentrated to dryness under vacuum. The residue (methylphthalhydrazide) was stirred for 2 hours with $5 \mathrm{~N} \mathrm{HCl}(25 \mathrm{~mL})$ and filtered. The aqueous and acid extracts were combined and concentrated hydrochloric acid ( $3 \mathrm{~mL})$ was added. After 2 hours, the aqueous solution was evaporated to give the $\beta$-lactam $N$ - $(\alpha$-carboethoxy- $\beta$-phenylethyl $)$-3-amino-4styryl-2-azetidinone (12) as a hydrochloride salt $(3.09 \mathrm{~g}, 85 \%)$; m.p. of the free amino $\beta$-lactam $110^{\circ} \mathrm{C}$;

${ }^{1} \mathrm{H}-\mathrm{NMR}: 1.30\left(3 \mathrm{H}, \mathrm{t}, \mathrm{CH}_{3}\right), 3.45\left(2 \mathrm{H}, \mathrm{d}, \mathrm{PhCH}_{2}\right) 4.34\left(2 \mathrm{H}, \mathrm{q}, \mathrm{OCH}_{2} \mathrm{CH}_{3}\right), 4.40(1 \mathrm{H}, \mathrm{t}, \underline{\mathrm{CHCO}} \mathrm{Et})$, $4.48(1 \mathrm{H}, \mathrm{dd}, \mathrm{J}=5.5 \mathrm{~Hz}, \underline{\mathrm{CHCH}}=\mathrm{CH}), 4.60(1 \mathrm{H}, \mathrm{m}, \underline{\mathrm{CHNH}} 2), 5.85(1 \mathrm{H}, \mathrm{dd}, \mathrm{PhCH}=\mathrm{CH}, \mathrm{J}=16 \mathrm{~Hz}), 6.4$ 
$(1 \mathrm{H}, \mathrm{d}, \mathrm{J}=12 \mathrm{Hx}, \mathrm{PhCH}=\underline{\mathrm{CH}}), 7.20(5 \mathrm{H}, \mathrm{m}, \underline{\mathrm{PhCH}} 2), 7.40(5 \mathrm{H}, \mathrm{m}, \underline{\mathrm{PhCH}}=\mathrm{CH}) ; \mathrm{IR}(\mathrm{KBr})\left(\mathrm{cm}^{-1}\right): 3300-$ $3400\left(\mathrm{H}_{2} \mathrm{~N}\right), 1780$ ( $\beta$-lactam CO), 1740 (ester CO); MS (m/z): $364\left(\mathrm{M}^{+}\right), 348\left(\mathrm{M}^{+}-\mathrm{NH}_{2}\right), 307\left(\mathrm{M}^{+}-\right.$ $\left.\mathrm{COCHNH}_{2}\right), 291\left(\mathrm{M}^{+}-\mathrm{CO}_{2} \mathrm{Et}\right), 104\left(\mathrm{PhCH}_{2} \mathrm{CH}\right), 91\left(\mathrm{PhCH}_{2}\right)$;Anal. Calc. for $\mathrm{C}_{22} \mathrm{H}_{24} \mathrm{~N}_{2} \mathrm{O}_{3}: \mathrm{C}, 72.51 ; \mathrm{H}$, 6.64 ; N, 7.69\%; found: C, 72.45; H, 6.74; N, 7.75\%.

General procedure for acylation of free amino $\beta$-lactam 12.

Pyridine (1.50 g, $18.96 \mathrm{mmol})$ was added to a solution of 12 (1.09 g, $3.00 \mathrm{mmol})$ followed by dropwise addition of phenylacetyl chloride $(0.93 \mathrm{~g}, 6.00 \mathrm{mmol})$ in $\mathrm{CH}_{2} \mathrm{Cl}_{2}(20 \mathrm{~mL})$. The solution was stirred for $2 \mathrm{~h}$. at $25^{\circ} \mathrm{C}$, then it was washed successively with $10 \% \mathrm{HCl}, 10 \% \mathrm{NaHCO}_{3}$ and water, dried $\left(\mathrm{MgSO}_{4}\right)$, filtered and the solvent was then evaporated to give the impure amide which was recrystallized from ethanol to give $N$-( $\alpha$-carboethoxy- $\beta$-phenylethyl)-3-phenylacetylamino-4-styryl-2azetidinone (14b, 3.86g, 80\%); m.p. $95^{\circ} \mathrm{C}$; ${ }^{1} \mathrm{H}-\mathrm{NMR}: 1.30\left(3 \mathrm{H}, \mathrm{t}, \mathrm{CH}_{3}\right), 3.45\left(2 \mathrm{H}, \mathrm{d}, \mathrm{PhCH}_{2}\right), 3.50(2 \mathrm{H}$,

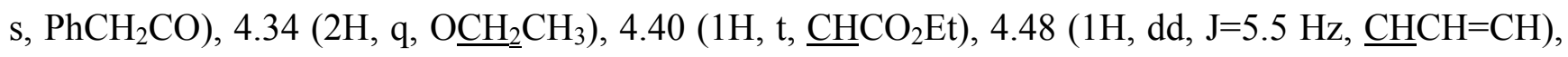
4.60 (1H, s, $\underline{\mathrm{CHNHCO}}), 5.85(1 \mathrm{H}, \mathrm{dd}, \mathrm{PhCH}=\mathrm{CH}, \mathrm{J}=16 \mathrm{~Hz}), 6.4(1 \mathrm{H}, \mathrm{d}, \mathrm{J}=12 \mathrm{Hx}, \mathrm{PhCH}=\underline{\mathrm{CH}}), 7.20$ 7.40 ( 15H, m, 3Ph); IR ( $\mathrm{cm}^{-1}$ ): 3400-3450 (NH), 1775 ( $\beta$-lactam CO), 1740 (ester CO), 1685 (amide $\mathrm{CO})$; $\mathrm{MS}(\mathrm{m} / \mathrm{z}): 482\left(\mathrm{M}^{+}\right), 409\left(\mathrm{M}^{+}-\mathrm{CO}_{2} \mathrm{Et}\right), 348\left(\mathrm{M}^{+}-\mathrm{PhCH}_{2} \mathrm{CONH}\right), 307\left(\mathrm{M}^{+}-\mathrm{PhCH}_{2} \mathrm{CONHCHCO}\right)$, $91\left(\mathrm{PhCH}_{2}\right)$; Anal. Calc. for $\mathrm{C}_{30} \mathrm{H}_{30} \mathrm{~N}_{2} \mathrm{O}_{4}: \mathrm{C}, 74.67 ; \mathrm{H}, 6.27 ; \mathrm{N}, 5.80 \%$; found: C, 74.75; H, 6.20; N, $5.90 \%$.

Compounds 14a , 14c, 14d and 15a-d were treated identically and their spectra were similar, except for the expected variations due to the amide side chains.

\section{References}

1. Palomo, C.; Aizpurua, J. M.; Ganboa, I.; Oiarbide, M. Eur. J. Org. Chem. 1999, 3223.

2. Staudinger, H. Liebigs Ann. Chem. 1907, 51, 356.

3. Ternansky, R. J.; Morin, J. M.; In The Organic Chemistry of $\beta$-lactams ; Georg, G.I., ed.; VCH: New York, 1993, p. 257.

4. (a) Jarrahpour A.A.; Shekarriz, M.; Taslimi, A. Molecules 2004, 9, 29; (b) Barton, D.H.R.; Getau-Olesker, A.; Anaya-Mateos, J.; Leophax, A.J.; Gero, S.D.; Chiaroni, A.; Riche, C. J. Chem. Soc. Perkin Trans 1 1990, 3211.

5. Bose, A. K.; Manhas, M. S.; Van der Veen, J. M.; Bari, S. S.; Wagle, D. R. Tetrahedron 1992, 48, 4831.

6. Gunda, T. E.; Sztaricskai, F. Tetrahedron 1997, 53, 7985.

7. (a) Araki, K.; O’Toole, J. C.; Weilch, J. T.; Bioorg. Med. Chem.Lett. 1993, 13, 2457; (b) Weilch, J. T.; Araki, K.; Kawcki, R.; Wichtowsk, J. A. J. Org. Chem. 1993, 58, 2454.

8. (a) Ojima, I. Acc. Chem. Res. 1995, 28, 383; (b) Ojima, I.; Delaloge, F. Chem. Soc. Rev. 1997, 26, 372 . 
9. Hashimoto, Y.; Ogasawara, T.; Hayashi, M.; Saigo, K. Heterocycles 2000, 52, 1001.

10. 10.Arunkumar, N.; Keyan, W.; Ramamurthy, V.; Scheffer, J. R.; Brain, P. Org. Lett. 2002, 4, 1443.

11. France, S.; Wack, H.; Hafez, A. M.; Taggi, A. E.; Witsil, D. R.; Lectka T. Org. Lett. 2002, 4, 1603

12. Hakimelahi, G. H.; Jarrahpour, A. A. Helv. Chim. Acta. 72, 1989, 1501.

13. Mukerjee, A. K.; Singh, A. K. Tetrahedron 1978, 34, 1731.

14. Doyle, T. W.; Belleau, B.; Luh, B. Y.; Conway, T. T.; Menord, M.; Douglas, J. L.; Chu, D. T. W.; Lim, G.; Morris, L. R.; Rivest, P.; Cosey, M. Can. J. Chem. 1977, 55, 484.

15. Bose,A. K.; Spiegelman, G.; Manhas, M. S. J. Am. Chem. Soc. 1968, 90, 4506

16. Palomo, C.; Aizpurua, J. M.; Gareia, J. M.; Galarza, R.; Legido, M.; Urchegui, R.; Roman, P.; Luque, A.; Server-Carrio, J.; Linden, A. J. Org. Chem. 1997, 62, 2070.

17. Kagan, H. B.; Basselier, J. J.; Luche, J. L. Tetrahedron Lett. 1964, 941.

18. Decazes, P. J.; Luche, J. L.; Kagan, H. B. Tetrahedron Lett. 1970, 3661.

19. Wolfe, S.; Hasan, S. K. Can. J. Chem. 1970, 48, 3572.

20. Kukolja, S.; Lammert, S.R. J. Am. Chem. Soc. 1975, 975582.

21. Sheehan, J. C.; Ryan, J. J. J. Am. Chem. Soc. 1951, 73, 4367.

22. Sheehan, J. C.; Dadic, M. J. Heterocycl. Chem. 1968, 5, 779.

23. Finegold, S. M.; Martin, W. J. Diagnostic Microbiology, $6^{\text {th }}$ ed.; Mosby: London, 1982; p. 450

Sample availability: Available from authors

C 2004 by MDPI (http://www.mdpi.org). Reproduction is permitted for noncommercial purposes. 